\title{
Peningkatan Kapasitas Pemuda Pelajar dalam Menghadapi Bencana di Kabupaten Pesisir Barat Provinsi Lampung
}

\author{
Dedy Hermawan', Bartoven Vivit Nurdin², Dodi Faedlulloh', Simon S. \\ Hutagalung ${ }^{1 *}$ \\ ${ }^{1}$ Administrasi Publik, Universitas Lampung, Bandar Lampung, 35145, Lampung, Indonesia \\ ${ }^{2}$ Sosiologi, Universitas Lampung, Bandar Lampung, 35145, Lampung, Indonesia
}

\begin{abstract}
.
Tujuan kegiatan pengabdian ini adalah: (1). Meningkatkan pengetahuan kelompok pemuda pelajar dalam mengidentifikasi potensi kegiatan di lingkungan sekitarnya, (2). Meningkatkan pengetahuan kelompok pemuda pelajar dalam mengidentifikasi dan mengelola peran untuk bangkit dari pandemi. Metode pengabdian yaitu berupa pelatihan dengan pendekatan pragmatis teoritis dan pendekatan pragmatis praktis. Dalam tahap pelaksanaan, kegiatan utama yang dilakukan adalah penyampaian materi berwujud pelatihan dengan skema: (1). Ceramah, Metode ini digunakan untuk menyampaikan teori dan konsep pokok yang harus dipahami dan dikuasai oleh peserta. Metode ceramah disertai tanya jawab dan studi kasus. (2). Diskusi, selain ceramah bervariasi, metode diskusi juga digunakan dalam kegiatan ini. Pelaksanaan kegiatan ini menghasilkan kesimpulan sebagai berikut: (1). Meningkatnya pengetahuan kelompok pemuda pelajar dalam mengidentifikasi potensi kegiatan di lingkungan sekitarnya. (2). Meningkatnya pengetahuan kelompok pemuda pelajar dalam mengidentifikasi dan mengelola peran untuk bangkit dari pandemi. Kedua kesimpulan itu didukung oleh hasil pres-test dan post-test yang menunjukkan bahwa kegiatan yang telah dilaksanakan mampu menghasilkan perubahan pengetahuan pada kelompok peserta kegiatan. Selain itu, observasi yang dilakukan menunjukkan jika materi yang disampaikan mampu memacu minat dan kesadaran mereka untuk lebih memahami kepentingan mereka terhadap materi tersebut.
\end{abstract}

Keywords.

Kelompok Pemuda, Kapasitas Pemuda, Resiliensi Bencana, Pandemi

\section{PENDAHULUAN}

Dalam upaya pengurangan risiko bencana, kegiatan pengelolaan bencana perlu diterapkan sebagai bagian dari kehidupan sehari-hari masyakarat. Paradigma pengelolaan kebencanaan yang berkembang dewasa ini lebih difokuskan untuk mencegah timbulnya risiko yaitu pada tahap pra bencana atau dikenal sebagai manajemen risiko [1]. Pada tahap ini penguatan kapasitas masyarakat dalam menghadapi bencana merupakan bagian yang

\section{* Corresponding author: simon.sumanjoyo@fisip.unila.ac.id}

Received 6 October 2021; Received in revised form 15 October 2021; Accepted 18 October 2021 
sangat penting. Penguatan kapasitas masyarakat dapat dibentuk dengan meningkatkan partisipasi aktif masyarakat dalam berbagai kegiatan pengelolaan bencana, khususnya yang berkaitan dengan pengenalan lingkungan sekitar [2].

Untuk semakin meningkatkan kapasitas masyarakat dalam menghadapi bencana, serta sebagai upaya mendukung pengelolaan bencana yang baik diperlukan upaya penguatan komunitas dalam berhadapan dengan bencana [3]. Kegiatan ini perlu dilakukan dengan melibatkan masyarakat dengan pertimbangan (1) masyarakat adalah pengguna yang akan berhadapan langsung dengan bencana tersebut, (2) disisi lain masyarakat merupakan pihak yang paling mengenali lingkungan sekitarnya. Proses penguatan kapasitas komunitas dengan memerlukan intervensi dalam wujud berbagai keahlian sehingga masyarakat yang dilibatkan nantinya akan mampu memanfaatkan pengetahuan dan keterampilan tersebut. Salah satu segmen yang paling penting terkait dengan upaya untuk meningkatkan peran kelompok pemuda pelajar dalam mitigasi bencana tersebut [4].

Dalam kegiatan pendahuluan, ditemukan jika peran pemuda pelajar dalam mitigasi bencana di desa pesisir sesar semangka belum sepenuhnya optimal. Untuk itu perlu diupayakan adanya kegiatan yang mendorong peran pemuda pelajar untuk lebih aktif dalam kegiatan mitigasi bencana, sekaligus memberikan keterampilan umum sebagai life skill. Kelompok pemuda pelajar juga memberikan respon positif terhadap kegiatan pelatihan yang mengarah kepada pengembangan pengetahuan dan keterampilan dalam bidang pengelolaan resiko bencana diwilayahnya masing-masing [5].

Dalam Undang Undang Republik Indonesia No 24 Tahun 2007 tentang Penanggulangan Bencana dijelaskan bahwa bencana adalah peristiwa atau rangkaian peristiwa yang mengancam dan mengganggu kehidupan dan penghidupan masyarakat yang disebabkan baik oleh faktor alam dan/atau faktor non alam maupun faktor manusia sehingga mengakibatkan timbulnya korban jiwa manusia, kerusakan lingkungan, kerugian harta benda, dan dampak psikologis. Bencana dapat dibedakan menjadi tiga yaitu bencana alam, bencana non alam, dan bencana sosial. Bencana alam menurut UURI No 24 Tahun 2007 adalah bencana yang diakibatkan oleh peristiwa atau serangkaian peristiwa yang disebabkan oleh alam antara lain berupa gempa bumi, tsunami, gunung meletus, banjir, kekeringan, angin topan, dan tanah longsor.

Sudibyakto (2018) menjelaskan bahwa pengelolaan kebencanaan merupakan sistem pengelolaan bencana alam merupakan kebutuhan nasional yang bersifat sinambung baik bagi pemerintah maupun masyarakat berkaitan dengan adanya bencana alam [6]. Sistem pengelolaan kebencanaan merupakan siklus yang terdiri dari rangkaian kegiatan yaitu kejadian bencana, penanganan darurat, rehabilitasi, rekonstruksi, mitigasim dan kesiapsiagaan menghadapi bencana berikutnya, kemudian terjadi bencana kembali dan seterusnya.

Kiranaratri et al. (2019) membedakan tindakan dalam siklus pengelolaan kebencanaan menjadi empat bagian pokok yaitu mitigasi, kesiapsiagaan, tanggap darurat, dan pemulihan [7]. Sementara itu, Suprayitno \& Soemitro (2019) membatasi aktivitas dalam pengelolaan kebencanaan menjadi tiga bagian pokok yaitu mitigasi dan kesiapsiagaan, respon, dan pemulihan [8]. Mitigasi mencakup pembangunan kapasitas dalam menghadapi bencana dan monitoring pra bencana, tanggap darurat mencakup observasi situasi kritis dan analisis data yang berhubungan dengan dampak bencana, sedangkan pemulihan mencakup dukungan-dukungan yang diperlukan selama proses pemulihan pasca bencana. Siklus bencana dalam kaitannya dengan penaksiran risiko bencana meliputi tanggap darurat, pemulihan, analisis bahaya, analisis kerentanan, mitigasi dan pencegahan, perencanaan kesiapsiagaan, serta prediksi dan peringatan untuk bencana selanjutnya 
Mitigasi dapat diartikan sebagai penjinakan, yaitu membuat sesuatu yang liar menjadi jinak atau yang keras menjadi lunak atau lembut. Bencana yang umumnya liar dengan upaya mitigasi diharapkan dijinakkan atau dilemahkan kekuatannya. Dalam UURI Nomor 24 Tahun 2007 tentang penanggulangan bencana dan PPRI Nomor 21 tahun 2008 tentang penyelenggaraan penanggulangan bencana dijelaskan bahwa mitigasi adalah serangkaian upaya untuk mengurangi risiko bencana, baik melalui pembangunan fisik ataupun penyadaran dan peningkatan kemampuan menghadapi ancaman bencana. Mitigasi bencana juga dapat didefinisikan sebagai tindakan untuk mengurangi dampak bencana yang antara lain dapat dilakukan dengan pembangunan fisik, peraturan perundangan, insentif, pendidikan dan pelatihan, penyuluhan sosial, kelembagaan, dan pengembangan sistem peringatan dini bahaya [6].

Mitigasi memiliki kedudukan yang sangat penting dalam pengelolaan bencana. Menurut PPRI Nomor 21 Tahun 2008 tentang Penyelenggaraan Penanggulangan Bencana, kegiatan mitigasi bencana dilakukan melalui (a) perencanaan dan pelaksanaan penataan ruang yang berdasarkan pada analisis risiko benana; (b) pengaturan pembangunan, pengembangan infrastruktur, dan tata bangunan; (c) penyelengaraan pendidikan, pelatihan, dan penyuluhan baik secara konvensional maupun modern. Menurut Baeda et al. (2016) cakupan mitigasi bencana sangatlah luas dan secara umum mencakup enam strategi mitigasi bencana yaitu pemetaan daerah rawan bencana, pemantauan, penyebaran informasi, sosialisasi dan penyuluhan, pelatihan/pendidikan, serta peringatan dini [9]. Dalam keperluan pelaksanaan mitigasi bencana dapat pula disusun SOP mitigasi bencana, yaitu pedoman yang memuat rangkaian urut-urutan kegiatan penjinakan becana yang disusun secara sederhana dan sistematis agar terjadi kesamaan tindak dalam menentukan langkah penyelesaian masalah, sehingga proses pelaksanaan pekerjaan lebih rapi serta lebih tertib dan hasil yang diperoleh lebih optimal, efisien, dan efektif.

Tujuan kegiatan pengabdian ini adalah: (1). Meningkatkan pengetahuan kelompok pemuda pelajar dalam mengidentifikasi potensi kegiatan di lingkungan sekitarnya, (2). Meningkatkan pengetahuan kelompok pemuda pelajar dalam mengidentifikasi dan mengelola peran untuk bangkit dari pandemi.

\section{METODE KEGIATAN}

Metode pengabdian yaitu berupa pelatihan dengan pendekatan pragmatis teoritis dan pendekatan pragmatis praktis. Dalam tahap pelaksanaan, kegiatan utama yang dilakukan adalah penyampaian materi berwujud pelatihan dengan skema: (1). Ceramah, Metode ini digunakan untuk menyampaikan teori dan konsep pokok yang harus dipahami dan dikuasai oleh peserta. Metode ceramah disertai dengan tanya jawab, dan penyampaian studi kasus. (2). Diskusi, selain ceramah bervariasi, metode diskusi juga digunakan dalam kegiatan ini. Metode ini digunakan untuk lebih meningkatkan pemahaman peserta pelatihan. Kaitan metode dan masalah dapat dijelaskan melalui ilustrasi berikut: 


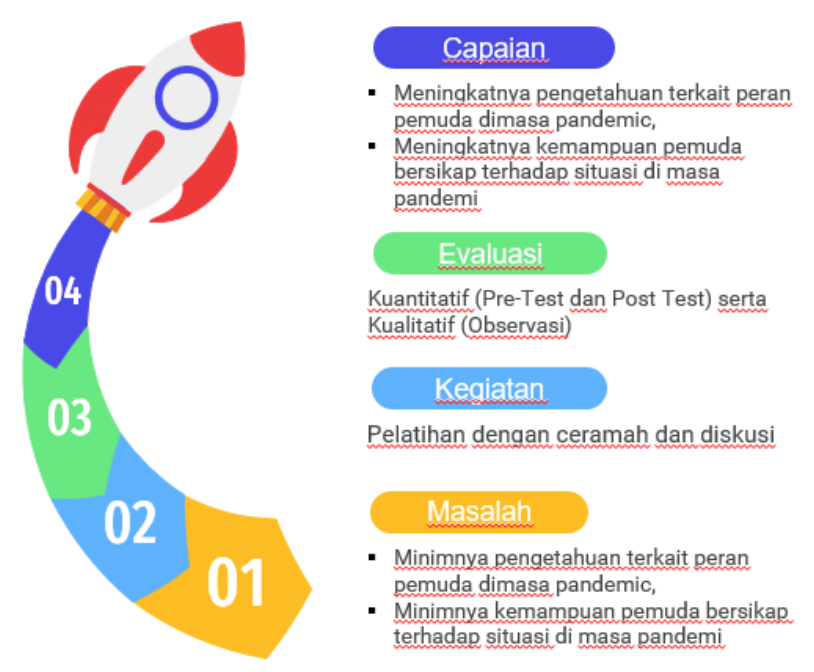

Gambar 1. Kerangka Pemecahan Masalah Dalam Kegiatan Pengabdian

Langkah dalam kegiatan pengabdian ini secara umum meliputi tahap persiapan, tahap pelaksanaan, dan tahap penyelesaian. Dalam tahap persiapan dilakukan kegiatan: (1) koordinasi dengan lembaga pemerintahan, masyarakat, serta organisasi kepemuda pelajaran tempat kegiatan pengadian dilaksanakan, (2) koordinasi dengan khalayak sasaran, (3) mempersiapkan materi, alat dan bahan yang digunakan, serta narasumber yang akan menyampaikan pelatihan. Alat dan bahan yang dipersiapkan antara lain modul pelatihan dan media yang diperlukan dalam pelaksanaan.

Pendekatan yang digunakan dalam kegiatan ini adalah pendekatan pragmatis teoritis dan pendekatan pragmatis praktis serta metode penyampaian sesuai dengan materi pelatihan yaitu ceramah bervariasi, demonstrasi, dan praktik. Pendekatan pragmatis teoritis digunakan agar materi jenis bahaya dan pemetaan potensi bencana yang cukup banyak dapat lebih mudah dipahami oleh peserta pelatihan. Berkaitan dengan tujuan tersebut, tidak semua materi akan disampaikan tetapi lebih diutamakan materi dasar yang berkaitan peran pemuda dalam pandemi. Dalam penyampaian materi digunakan beberapa metode yaitu: (1) ceramah, untuk menyampaikan materi yang membutuhkan kejelasan konsep dan penjelasan secara lebih detail, termasuk menyampaikan contoh-contoh yang dapat dengan mudah dicerna oleh peserta pelatihan, (2) tanya jawab antara peserta dengan pemateri yang merupakan bentuk konfirmasi dan pendalaman pengetahuan yang berguna memberi kemantapan wawasan dan sikap para peserta kegiatan.

Khalayak sasaran dalam kegiatan pengabdian ini adalah kelompok Pemuda di Kabupaten Pesisir Barat, khususnya anggota organisasi pemuda Karang Taruna yang terlibat aktif dalam aktivitas kepemudaan baik tingkat desa maupun kecamatan. Khalayak sasaran dibatasi pada kelompok pemuda dengan mempertimbangkan potensi yang dimiliki dan peran aktif jangka panjang dalam kegiatan pengelolaan bencana, dapat mengembangkan sendiri kegiatan mitigasi non struktural pada masa mendatang, serta dapat melakukan kerjasama dengan berbagai pihak dalam rangka pelaksanaan pengelolaan kebencanaan di daerahnya.

Sementara dalam aspek evaluasi kegiatan, terdapat dua rancangan evaluasi yang akan digunakan untuk kegiatan ini, yaitu:(1). Evaluasi secara kuantitatif melalui pre-test dan posttest. Rancangan tersebut digunakan untuk mengukur perubahan pengetahuan dan kemampuan seluruh peserta kegiatan. Pengukuran ini dilakukan melalui formulir google yang dibagikan kepada pendaftar kegiatan (pre-test) dan peserta yang telah menyimak materi pelatihan online (post-test). Analisis dilakukan terhadap pendaftar kegiatan yang juga 
telah menyimak materi pelatihan. (2). Evaluasi secara kualitatif dilakukan melalui diskusi/ tanya jawab dengan pemantauan selama proses pemaparan materi yang disajikan berlangsung antara penyaji materi dengan peserta/sasaran kegiatan, khususnya yang terkait dengan aspek yang berhubungan dengan tema kegiatan. Guna menjaga keberlanjutan program ini, proses pendampingan dilaksanakan secara periodik dalam rentang waktu satu tahun sejak kegiatan ini dilaksanakan. Pada masa mendatang dapat dilakukan kajian kembali guna menentukan derajat perubahan optimal yang telah dicapai.

\section{HASIL PELAKSANAAN KEGIATAN}

Kegiatan dimulai dengan penyampaian sambutan oleh Dedy Hermawan yang mewakili tim pelaksana kegiatan pengabdian pada masyarakat mengutarakan maksud dan tujuan dari kegiatan ini, dimana kegiatan ini bertujuan untuk mendukung dan mendorong penguatan kapasitas kelompok pemuda di masa pandemi. Pemuda sejatinya merupakan kelompok yang memiliki energi dan kapasitas untuk mendukung masyarakat, serta tidak membiasakan diri untuk larut dalam ketakutan, kesedihan dan kondisi yang serba tidak pasti ini. Selanjutnya diberikan sambutan oleh Ketua Karang Taruna Pesisir Barat, Bapak Suryadi beserta jajaran anggotanya. Disampaikan jika acara ini merupak bentuk kesempatan bagi kelompok pemuda untuk mendengar informasi dan materi yang sifatnya memperkuat, bukan melemahkan. Diharapkan nantinya pemuda justru akan mampu memanfaatkan masa pandemi ini sebagai celah untuk lebih berintrospeksi dan memperkuat diri dengan beragam pengetahuan dan keterampilan baru.

Selanjutnya dilaksanakan penyampaian materi yang terlebih dahulu dilakukan Dody Faedlulloh dengan paparan berjudul Peningkatan Kapasitas Pemuda Pelajar Dalam Masa Pandemi Covid-19. Paparan tersebut disampaikan dalam bentuk slide power point dan diikuti oleh seluruh peserta kegiatan. Materi yang disampaikan pada dasarnya menganjurkan kelompok pemuda untuk aktif dalam tiga hal: aktif memperkuat kapasitas diri, aktif memperkuat kualitas keluarga dan aktif memperkuat ketahanan bangsa. Materi ini sangat diapresiasi oleh peserta, dimana terdapat beberapa pertanyaan yang bersifat memperdalam pengetahuan mereka. Adapun gambar dari pelaksanaan kegiatan itu dapat dicermati dari gambar dibawah ini:

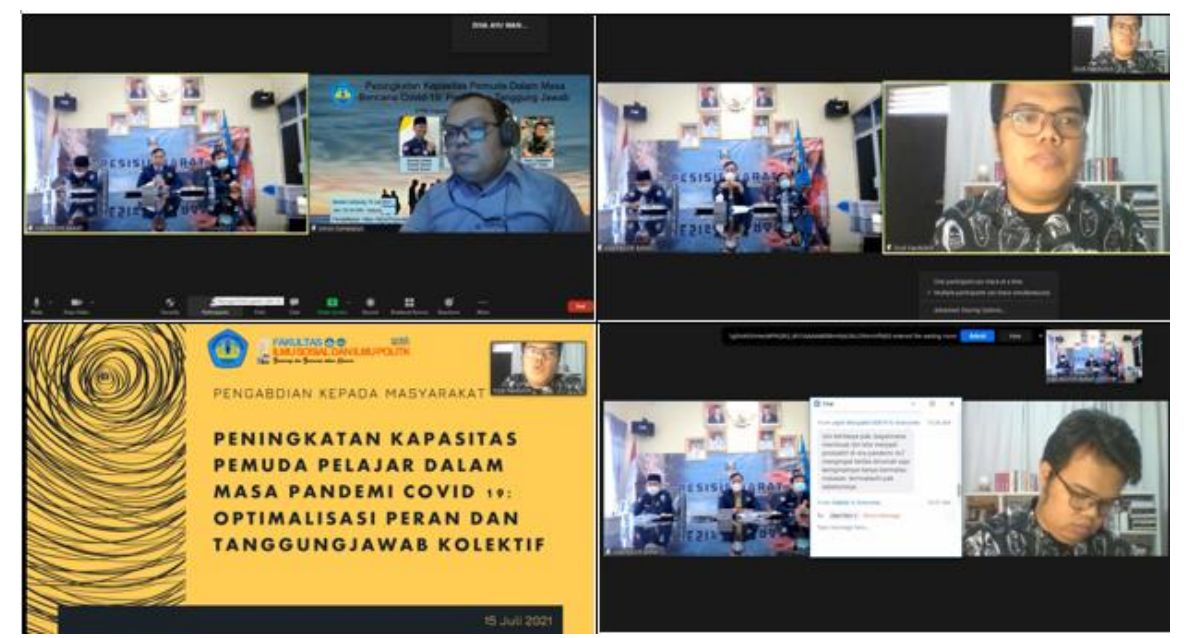

Gambar 2. Pelaksanaan Pelatihan Online Peningkatan Kapasitas Pemuda di Masa Pandemi

Selanjutnya disampaikan materi oleh Simon S. Hutagalung yang mempertegas peran pemuda dimasa pandemi, dimana pada beberapa contoh pada daerah lain mereka mampu menjadi motor penanganan pandemi. Beberapa contoh tersebut seperti aktivitas menjadi 
relawan kegawatdaruratan, relawan pemakaman atau melakukan gerakan dan kegiatan yang membantu kelompok terdampak pandemi. Beberapa gerakan yang dilakukan dianggap mampu mengurangi penderitaan beberapa kelompok masyarakat yang terdampak pandemi itu. Beberapa contohnya seperti upaya mendirikan dapur umum untuk keluarga yang sedang isolasi mandiri, mendirikan tempat isolasi mandiri di gedung sekretariat kepemudaan atau melakukan gerakan donasi bagi kelompok masyarakat yang terkena pemutusan hubungan kerja. Materi ini diapresiasi oleh peserta dan diharapkan mereka juga mampu mengikuti contoh baik tersebut.

Pada bagian selanjutnya merupakan sesi tanya jawab antara peserta pelatihan dengan pemateri, pada bagian ini Dedy Hermawan dan Bartoven Vivit turut serta menjawab sekitar 8 pertanyaan yang muncul, diantaranya bertanya tentang aspek praktis dan taktis yang harus dilakukan oleh pemuda dalam rangka memperlajari pengetahuan dan keterampilan baru, khususnya pemuda yang berada di daerah. Hal ini sebenarnya berkaitan dengan persepsi, dimana seseorang akan dihadapkan kepada pilihan untuk melihat situasi diri dan sekitarnya. Kondisi tersebut yang menjadi peluang guna dikelola sebagai bagian dari pengembangan diri. Pemuda desa misalnya bisa mempelajari metode metode baru dan inovatif dalam perkebunan atau beternak, dan nantinya berupaya untuk menerapkan pengetahuan tersebut di lingkungannya. Ada juga pertanyaan terkait peran pemuda dalam penanganan covid, dimana hal ini sebenarnya juga terkait dengan aspek pengetahuan. Pemuda yang sudah memiliki pengetahuan tentang protokol kesehatan misalnya, seharusnya mampu mengedukasi keluarga dan masyarakat sekitar. Pemuda yang sudah paham tentang literasi digital misalnya, sebaiknya mengedukasi warga terkait berita hoax yang menyesatkan, bahkan bisa membahayakan dimasa pandemi ini.

\section{Hasil Pelaksanaan Kegiatan}

Setelah materi disampaikan maka dilakukan evaluasi dengan memberikan kuisioner berbentuk google form kepada peserta kegiatan. Post-test kemudian dianalisis dan dibandingkan dengan pre-test yang telah disebar pada saat sebelum acara dilakukan. Adapun hasil analisis tersebut disajikan dalam bentuk tabel sebagai berikut:

Tabel 1. Hasil Penilaian Pre-Test dan Post-Test

\begin{tabular}{|c|c|c|c|c|c|c|c|c|c|c|c|c|}
\hline \multirow{2}{*}{ No } & \multirow{2}{*}{ Poin Evaluasi } & \multirow{2}{*}{ Kode } & \multicolumn{4}{|c|}{ Pre-Test } & \multicolumn{4}{|c|}{ Post-Test } & \multicolumn{2}{|c|}{ Perubahan } \\
\hline & & & $\mathbf{S}$ & $\%$ & TS & $\%$ & $\mathbf{S}$ & $\%$ & TS & $\%$ & $\mathbf{S}$ & TS \\
\hline 1 & $\begin{array}{l}\text { Upaya berperan sebagai aktor yang } \\
\text { mengedukasi }\end{array}$ & $\mathrm{P} 1$ & 55 & 79.7 & 14 & 20.3 & 65 & 94.2 & 4 & 5.8 & 14.5 & -14.5 \\
\hline 2 & Upaya menjaga harapan dan inisiatif & $\mathrm{P} 2$ & 50 & 72.5 & 19 & 27.5 & 55 & 79.7 & 13 & 18.8 & 7.2 & -8.7 \\
\hline 3 & $\begin{array}{l}\text { Upaya meningkatkan pengetahuan atau } \\
\text { keterampilan }\end{array}$ & P3 & 51 & 73.9 & 18 & 26.1 & 65 & 94.2 & 1 & 1.4 & 20.3 & -24.6 \\
\hline 4 & $\begin{array}{l}\text { Upaya untuk tidak mengeluh dan } \\
\text { mengutuk keadaan }\end{array}$ & $\mathrm{P} 4$ & 45 & 65.2 & 24 & 34.8 & 46 & 66.7 & 20 & 29.0 & 1.4 & -5.8 \\
\hline 5 & Upaya menjaga sikap optimis dan bahagia & P5 & 52 & 75.4 & 17 & 24.6 & 64 & 92.8 & 0 & 0.0 & 17.4 & -24.6 \\
\hline 6 & $\begin{array}{l}\text { Upaya melakukan kegiatan bersama } \\
\text { (teman, organisasi atau kelompok lain) }\end{array}$ & P6 & 42 & 60.9 & 27 & 39.1 & 43 & 62.3 & 21 & 30.4 & 1.4 & -8.7 \\
\hline 7 & $\begin{array}{l}\text { Upaya mendukung program pemerintah di } \\
\text { masa pandemi }\end{array}$ & P7 & 57 & 82.6 & 12 & 17.4 & 58 & 84.1 & 5 & 7.2 & 1.4 & -10.1 \\
\hline
\end{tabular}

Dari tabel tersebut nampak jika perubahan positif terjadi pada seluruh point evaluasi, 
khususnya dalam kategori setuju yang cenderung mengalami peningkatan pada saat posttest. Adapun perubahan yang tertinggi terjadi pada point upaya meningkatkan pengetahuan atau keterampilan (20,3\%), disusul point upaya menjaga sikap optimis dan bahagia $(17,4 \%)$ dan upaya berperan sebagai aktor yang mengedukasi (14,5\%). Ketiga point ini memang paling dominan disorot dalam penyampaian materi dan sesi tanya jawab. Hal ini sekaligus menunjukkan jika kelompok pemuda yang menjadi sasaran kegiatan ini menyadari jika pandemi harus dihadapi dengan optimis, lalu direspon dengan memanfaatkan waktu dengan cara mempelajari pengetahuan atau keterampilan baru atau turut mengambil peran sebagai pelaku yang mengedukasi masyarakat dalam hal penerapan protokol kesehatan dan sejenisnya.

Sementara pada beberapa point yang perubahannya sangat minim terjadi pada point upaya untuk tidak mengeluh dan mengutuk keadaan $(1,4 \%)$, upaya melakukan kegiatan bersama $(1,4 \%)$ dan upaya untuk mendukung program pemerintah dimasa pandemi $(1,4 \%)$. Hal ini menunjukkan jika kelompok sasaran dalam kegiatan ini menganggap jika pandemi sudah wajar akan menghasilkan keluhan karena banyak dampak negatif yang diakibatkannya, selain itu di masa pandemi juga tidak lagi menarik untuk melakukan kegiatan berkumpul bersama karena beresiko untuk menyebarkan resiko virus. Kemudian mereka juga menganggap program pemerintah dalam masa pandemi akan mereka dukung, namun program yang sifatnya membantu masyarakat juga sejatinya didukung oleh pemerintah. Guna mencermati sebaran jawaban pada pres test dan post tes maka dapat disajikan gambar sebagai berikut:

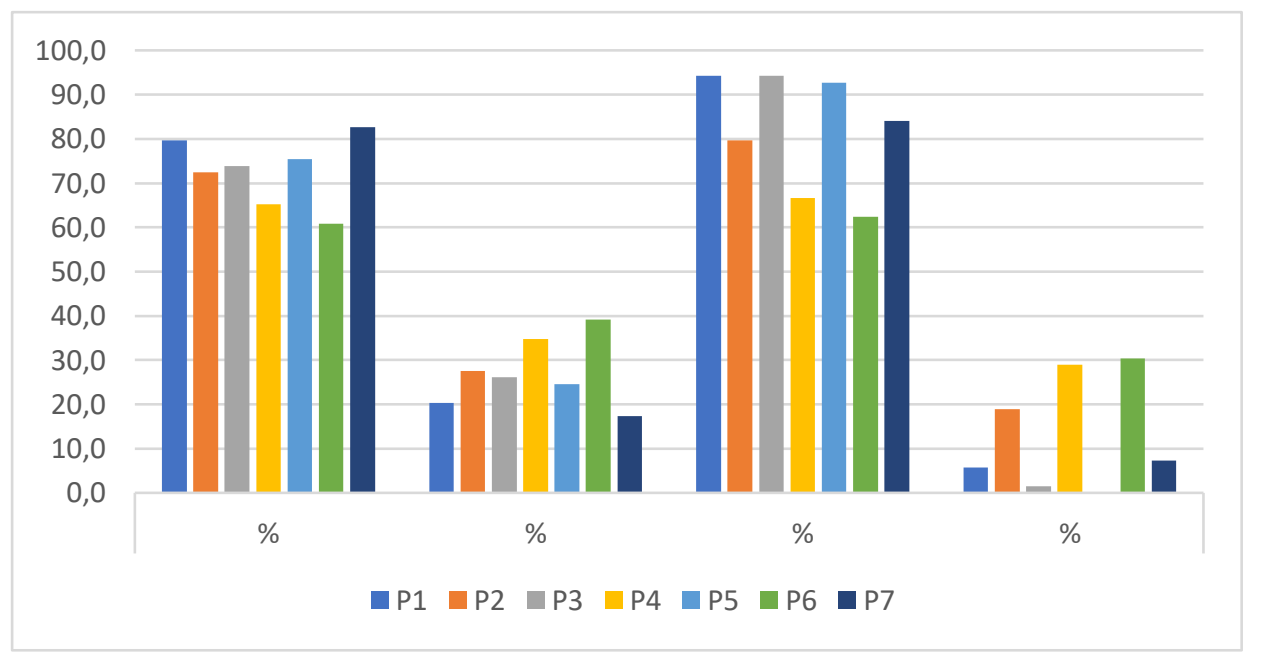

Gambar 3. Perbandingan Skor Pre-Test dan Post-Test

Dari gambar diatas nampak jika lonjakan persentase pada pilihan jawaban setuju terjadi pada kolom post-test. Hal ini menunjukkan jika materi yang diberikan oleh narasumber mampu menghasilkan penambahan pengetahuan pada kelompok sasaran, mereka menjadi berubah yang tadinya tidak terlalu memahami aspek yang ditanyakan pada pres-test menjadi tercerahkan pada saat materi disampaikan. Oleh karena itu, dapat disimpulkan jika kegiatan ini mampu menghasilkan perubahan pengetahuan pada kelompok peserta kegiatan. Selain itu, melalui observasi yang diamati dari intentitas peserta mengikuti acara hingga akhir kegiatan dan inisiatif mereka untuk bertanya melalui kolom chat menunjukkan jika materi yang disampaikan mampu memacu minat dan kesadaran mereka untuk lebih memahami substansi dan kepentingan mereka terhadap materi tersebut. Pada akhirnya, peserta kegiatan mengapresiasi positif kegiatan ini dan mengharapkan lebih banyak kegiatan lanjutan yang diberikan kepada kelompok pemuda, khususnya Karang Taruna 
Kabupaten Pesisir Barat.

\section{KESIMPULAN}

Pelaksanaan kegiatan ini menghasilkan kesimpulan sebagai berikut: (1). Meningkatnya pengetahuan kelompok pemuda pelajar dalam mengidentifikasi potensi kegiatan di lingkungan sekitarnya. (2). Meningkatnya pengetahuan kelompok pemuda pelajar dalam mengidentifikasi dan mengelola peran untuk bangkit dari pandemi. Kedua kesimpulan itu didukung oleh hasil pres test dan post-test yang menunjukkan bahwa kegiatan yang telah dilaksanakan mampu menghasilkan perubahan pengetahuan pada kelompok peserta kegiatan. Selain itu, melalui observasi yang diamati dari intentitas peserta mengikuti acara hingga akhir kegiatan dan inisiatif mereka untuk bertanya melalui kolom chat menunjukkan jika materi yang disampaikan mampu memacu minat dan kesadaran mereka untuk lebih memahami substansi dan kepentingan mereka terhadap materi tersebut

\section{UCAPAN TERIMA KASIH}

Terima kasih diucapkan kepada Ketua dan Sekretaris LPPM Universitas Lampung beserta seluruh stafnya, khususnya yang telah mendukung melalui pendanaan DIPA BLU Unila skema PPM Unggulan Tahun 2021. Dekan FISIP Unila dan jajarannya, para dosen dan seluruh pihak yang telah mendukung pelaksanaan kegiatan ini.

\section{DAFTAR PUSTAKA}

[1] Anggraeni, L. (2020). Penanggulangan bencana banjir bandang di desa sanggi Padangcermin Tanggamus Lampung. Jurnal Pengabdian Kepada Masyarakat, 1(1), Article 1. http://jurnal.umitra.ac.id/index.php/ANDASIH/article/view/373

[2] Ariyanto, D. (2018). KOORDINASI KELEMBAGAAN DALAM MENINGKATKAN EFEKTIVITAS BADAN PENANGGULANGAN BENCANA DAERAH. Management Review, 2(1), 161-171. https://doi.org/10.25157/jmr.v2i1.1118

[3] Yaneri, A. (2020). INTERVENSI KOMUNITAS: STRATEGI PENANGGULANGAN BENCANA BERBASIS MASYARAKAT DI KABUPATEN DELI SERDANG. Jurnal Papatung: Jurnal Ilmu Administrasi Publik, Pemerintahan Dan Politik, 3(2), 12-26. https://doi.org/10.660303/japp.v3i2.72

[4] Nahak, P. G., Mauta, M. C., \& Daud, D. D. A. A. (2018). Tinjauan Mitigasi Bencana Tsunami di Kawasan Wisata Pesisir Teluk Kupang. JUTEKS: Jurnal Teknik Sipil, 3(1), 244-249. https://doi.org/10.32511/juteks.v3i1.198

[5] Santoso, D., Yamin, M., \& Makhrus, M. (2019). Penyuluhan Tentang Mitigasi Bencana Tsunami Berbasis Hutan Mangrove Di Desa Ketapang Raya Kecamatan Keruak Lombok Timur. Jurnal Pengabdian Magister Pendidikan IPA, 1(2). https://doi.org/10.29303/jpmpi.v1i2.242

[6] Sudibyakto, H. A. (2018). Manajemen Bencana di Indonesia ke Mana? UGM PRESS.

[7] Kiranaratri, A. H., Simarmata, N., \& Hidayat, D. (2019). ANALISIS POTENSI TINGKAT BENCANA BANJIR DAERAH ALIRAN SUNGAI WAY KURIPAN KOTA BANDAR LAMPUNG. Rekayasa Sipil, 13(2), 147-152. https://doi.org/10.21776/ub.rekayasasipil.2019.013.02.10

[8] Suprayitno, H., \& Soemitro, R. A. A. (2019). Pemikiran Awal tentang Prinsip Tindakan Mitigasi Preventif Resiko Bencana Alam bagi Manajemen Aset Infrastruktur \& Fasilitas. Jurnal Manajemen Aset Infrastruktur \& Fasilitas, 3(0). https://doi.org/10.12962/j26151847.v3i0.5187

[9] Baeda, A. Y., Klara, S., Hendra, H., \& Muliyati, R. (2016). Mitigasi Bencana Tsunami di Pantai Losari Makassar, Sulawesi Selatan. Jurnal Penelitian Enjiniring, 20(1), 21-27. 